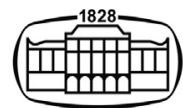

AKADÉMIAI KIADÓ

\title{
The Immortality Key: The Secret History of the Religion with No Name
}

\author{
JERRY B. BROWN*
}

\section{Journal of Psychedelic Studies}

$5(2021) 1,5-8$

DOl:

10.1556/2054.2021.00170

(C) 2021 The Author(s)

\section{BOOK REVIEW}

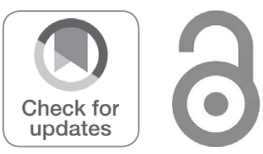

*Corresponding author. E-mail: jbbrown@gate.net
Global and Sociocultural Studies, Florida International University, Miami, FL, USA

Review of The Immortality Key: The Secret History of the Religion with No Name by Brian Muraresku, St. Martin's Publishing Group, 2020, ISBN: 9781250207142 (hardcover), 460 pp, \$20.63.

Received: February 1, 2021 - Accepted: February 14, 2021

Published online: March 11, 2021

Brain Muraresku is a practicing attorney and a student of ancient languages (Greek, Latin and Sanskrit), whose twelve-year odyssey through the archives of Western religion culminated in the publication of The Immortality Key (TIK). According to Muraresku, this work, which "presents the pagan continuity hypothesis with a psychedelic twist," addresses two fundamental questions: "Before the rise of Christianity, did the Ancient Greeks consume a secret psychedelic sacrament during their most famous and well-attended religious rituals? Did the Ancient Greeks pass a version of their sacrament along to the earliest, Greekspeaking Christians, for whom the original Holy Communion or Eucharist was, in fact, a psychedelic Eucharist?"

TIK is a fascinating, audacious and important book. It is fascinating for general readers and scholars alike in the journalistic manner in which it investigates and interprets difficultto-access data from diverse fields. Muraresku takes us along on his often breathless journey, describing visits to the nonpublic ceramic collections of the Louvre Museum in search of the pagan roots of Christian wine; explorations of Rome's vast catacombs to decipher archaeological traces of entheogen use in early Christian symbols; and rare access to recently-opened Vatican archives to translate Inquisition proceedings documenting the dual persecution of mothers and daughters in medieval witchcraft trials.

This book is audacious because it tackles and purports to resolve some of the most controversial questions in Catholic Church history and Indo-European archeology. Does Christianity have a psychedelic history? Who were the ancient Indo-Europeans and were their soma/haoma rituals the inspiration for the kykeon potion in the Greek Eleusinian Mysteries and the Eucharist in early Christianity? These Ancient Greek Mysteries are a landmark in the psychedelic study of world religions because they were practiced annually for nearly 2,000 years, from about $1500 \mathrm{BC}$ to $380 \mathrm{AD}$ when the Catholic Church became the official religion of the Roman Empire after which Eleusis was destroyed as a pagan temple.

And, TIK is important because, based on Muraresku's conversations with archaeochemists at the University of Pennsylvania and MIT and on his interpretation of until-now obscure archaeobontanical discoveries in Spain, it reports on the first direct chemical evidence of entheogen use in the Eleusinian Mysteries. In the process, The Immortality Key resurrects and rescues the life work of Carl A.P. Ruck, a Classics professor expert in the rites of Dionysus and Catholic Church history, from four decades of academic exile.

In 1978, Ruck coauthored, with ethnomycologist R. Gordon Wasson (1898-1986) and chemist Albert Hoffman (1906-2008), The Road to Eleusis: Unveiling the Secrets of the Mysteries, which proposed that the kykeon, the secret potion consumed by initiates at Eleusis, contained a hallucinogenic ergot. The book presents evidence, analyzed by Hoffman at Sandoz laboratories in Switzerland, that ergots of wheat and barley contain alkaloids of the ergonovine group and traces of lysergic acid amide (a less potent relative of LSD), both psychoactive. The Homeric "Hymn to Demeter," the Greek goddess who gifted mortals the Eleusinian Mysteries, states that the kykeon was prepared from barley, water and mint. Based on this information, the researchers presumed that the wild barley found on the Rarian plains surrounding Eleusis in the second millennium BC was host to an ergot-containing, watersoluble hallucinogenic alkaloid-the purple sclerotia of Claviceps purpurea, a parasitic fungal growth found on rye, barley, wheat and wild grasses. 
Publication of The Road to Eleusis enhanced the already distinguished careers of Wasson, widely acknowledged as the founder of ethnomycology, and of Hoffman, renowned worldwide for his discovery of LSD. But, for Ruck's future as a tenured Classics professor at Boston University (BU), it was devastating. The book came out in the late 1970s, the decade of President Nixon's War on Drugs, during an era when BU president John Silber was a staunch conservative and a Platonic scholar well-versed in the Classics. After receiving a copy of The Road to Eleusis, Silber never commented on it to Ruck, but instead summarily consigned him to the academic equivalent of solitary confinement. In short order, Ruck was removed as department chair and prohibited from teaching graduate courses, while BU scholars in other disciplines were warned against collaborating with him. His courses on entheogens were dropped from the curriculum and doctoral candidates were forewarned that they might not find employment in Classics departments if Ruck chaired their dissertation committee.

Reluctant to even consider that the Ancient Greeks, revered as founders of Western Civilization, consumed drugs in religious rituals, Ruck's colleagues in Classics studies responded to The Road to Eleusis either with scathing criticism or, for the most part, resounding silence. Chastened but undeterred Ruck has spent the last four decades researching the presence of entheogens in Ancient Greece and in medieval and Renaissance Christianity. Masterfully weaving together data from art history, church archives and pagan mythology, Ruck has coauthored some of the most erudite and original studies of the entheogenic roots of Christianity, including The Apples of Apollo: Pagan and Christian Mysteries of the Eucharist (2001), Mushrooms, Myth and Mithras: The Drug Cult that Civilized Europe (2011), and The Effluents of Deity: Alchemy and Psychoactive Sacraments in Medieval and Renaissance Art (2012).

\section{RESURRECTION OF CARL A.P. RUCK}

TIK's most significant contribution is grounded in Muraresku's interpretation of investigations surrounding Mas Castellar de Pontós, an archaeological site in Emporion, an ancient Greater Greece colony founded in the sixth century BC in present day Catalonia in northeastern Spain. Here Greek citizens, who could not sail across the Mediterranean to celebrate the annual mysteries at Eleusis, had constructed a sanctuary dedicated to Demeter and her daughter Persephone. The sanctuary, which contains an altar of Pentelic marble imported from the homeland, was constructed between 250-180 BC and excavated over three decades starting in the 1990s by archaeologist Enriqueta Pons.

Pouring through relevant archaeological studies of the 2000s, including publications in Catalan, Muraresku came across the name of Jordi Juan-Tresserras, an archaeobotantist from the University of Barcelona. Muraresku reports that, in a brief paragraph buried in an article in a peerreview Spanish journal, Juan-Tresserras mentions the "apparently unremarkable discovery" of "the remains of ergot sclerotia' at Mas Castellar de Pontós in not one, but two different artifacts connected to Pons's iconic 'domestic chapel'." The chemical signatures of the fungi were found in the remains of teeth embedded in a human jawbone and in a "miniature chalice," a tiny cup similar to the kernos in which the kykeon was served to initiates in the telesterion, the inner sanctuary at Eleusis.

In a heartwarming scene, Muraresku describes how he invites the "old professor" Ruck to accompany him on a visit with Pons in Catalonia for a tour of the Museu de Arqueologia de Catalunya-Giron, home to artifacts from Mas Castellar de Pontós. Specifically, Muraresku's revelations afford Ruck the satisfaction, albeit belatedly, of seeing the conclusions of The Road to Eleusis scientifically validated through archaeochemistry whose analytic technologies were not available four decades ago when the book was first published.

Generally and of broader theoretical significance, in addressing TIK's second major question-regarding possible Ancient Greek roots of the psychoactive Eucharist celebrated by early Christians-Muraresku's enthusiastically embraces Ruck's ideas on the entheogenic origins of religion, including Christianity. In doing so, he resurrects these controversial concepts from decades of obscurity and catapults them into contemporary academic discussions including a presentation at Harvard Divinity School and into public awareness through a widely-watched interview with celebrity podcast host Joe Rogan.

\section{THE BEER REVOLUTION}

In summarizing his own research and Ruck's master theory, Muraresku purports to explain: "How psychedelics were the shortcut to enlightenment that founded Western civilization: first in the Eleusinian Mysteries, then in the Dionysian Mysteries. How paleo-Christianity inherited this tradition from the Ancient Greeks, later passing it to the witches of the Middle Ages and Renaissance. And how the Vatican would repeatedly suppress the original, psychedelic Eucharist to rob Christians of the beatific vision-first in Europe, and then around the world after the Catholic colonization of Africa, Asia, and Latin America. A truly global conspiracy."

In proposing that psychedelics "founded Western civilization," Muraresku echoes the iconoclastic views of archaeochemists who hold that the Agricultural Revolution was actually a "Beer Revolution," arguing that the bonds of civilization were forged around the communal sharing and technological innovation of a ritual potion: graveyard beer. Tracing the origins of "stone age mortuary rituals to venerate the dead" back to two Megalithic archaeological sites-the 13,000-year-old Natufian burial site within the Raqefet Cave in Israel and 12,000-year-old Göbekli Tepe in southeastern Turkey-TIK further postulates that ancient beer spiked with mind altering drugs was used in early rituals to achieve "ecstatic communion with the ancestors." 
After affirming that there is a "sacramental link, however delicate, between prehistoric beer and the psychoactive kukeon * at Eleusis," TIK strives to connect the dots in order to forge a concatenation of direct lineal descent: from Eleusis to entheogen-laced ritual wine of Dionysus and the sacramental wine of the early Eucharist; to the secret potions of medieval witches; and even correlates these precedents with the psilocybin-induced mystical experiences reported in contemporary NYU and Johns Hopkins clinical trials with cancer patients. Projecting this psychedelic trend line into the future, TKI suggests that it portends an entheogenic "Reformation to end all Reformations" that is emerging to fill the void felt by the more than one billion people globally who are "religiously unaffiliated" and "spiritual but not religious.”

TIK argues that this entheogen-induced ecstatic vision, the ego-death experience that allows you to "die before you die" thus granting the living a reassuring glimpse of immortality, has over millennia and in diverse cultures served as the common element in the "religion with no name." The pervasive underlying premise of TIK is that all religion originates from the ingestion of psychedelic concoctions of mind-altering beer and wine. And, conversely, that the only religious experience sufficiently reliable, fastacting and powerful enough to convert the masses into true believers is an altered state of consciousness induced by psychedelics.

\section{THE RELIGION HAS A NAME: "SHAMANISM"}

Viewed from an anthropological perspective, there are multiple flaws both conceptual and historical with this line of reasoning. The first is with the basic assumption enshrined in the book's subtitle that we are dealing with a "religion with no name." In fact, for anthropologists the religion does have a name: "shamanism." Furthermore, among diverse cultures that have historically practiced or currently practice some form of shamanism, the religion is known by many different names. In addition to simply being called the "mysteries" by the Ancient Greeks, it is known as the "Little-One-Who-Springs-Forth" among the Mazatec of Mexico and was known as "Soma" among the Aryan invaders of Ancient India, to name but a few. Muraresku asserts that this no-name religion "survived for millennia, in the total absence of the written word." To the contrary, in the case of the Rigveda, one of the world's oldest religious texts written in Sanskrit some 3,500 years ago, the tenth mandala is devoted to praise of Soma. This belies Muraresku's narrative that TIK has unearthed an unnamed religion which "had been deleted completely from the human record."

In Mircea Eliade's classic definition shamanism is described as "archaic techniques of ecstasy," referring to ancient techniques for inducing the flight of the soul. As Peter Furst, an anthropologist who studied the peyote hunt of the Huichol of Mexico, explains in Hallucinogens and Culture (1976), psychoactive plants are by no stretch of the imagination the only, or even the main way in which indigenous people achieved this altered state of consciousness. Other non-chemical methods include: fasting, self-mutilation, trance dancing, sensory overload, meditation, chanting, and solitary vision quests. Essentially, TIK's fundamental premise regarding the primary role of psychedelics in religion experience is wrong because Muraresku fails to consider anthropological evidence that contravenes his thesis. (While TIK offers one cursory acknowledgment that "Lying down in a cave for a few days might get the job done," it summarily dismisses this option as too time consuming and too challenging for widespread adoption.)

All too often throughout TIK, in order to defend his thesis Muraresku overreaches and presents speculation as fact, a concptual leap only achieved by distorting history and disregarding contrary viewpoints in the literature. As one example, TIK argues that "Not only is there evidence of psychedelic beer and wine at the heart of the Greek and Christian Mysteries, but there is also evidence of their suppression by the religious authorities," adding for emphasis that this took place systematically from the fourth century on "beneath the jackboots of the Roman Catholic Church." Here Muraresku completely ignores research by Samorini (1998), Brown and Brown (2016) and Brown and Brown (2019), and even by Ruck and Hoffman (2012) whom he cites extensively, documenting numerous artistic images of entheogenic mushrooms in chapels and churches, as well as in the high holy places of Christianity such as the cathedrals at Chartres and Canterbury, during the Middle Ages and the Renaissance.

As another example, in an effort to defend its claims about the ongoing suppression of "witches" from the fourth century on by the Vatican bureaucracy, TIK states that "the witches of Dionysus and the witches of Jesus were fairly indistinguishable." But this conflates the multifaceted concept of "witchcraft" as practiced in different time periods by diverse cultures. Furthermore, it ignores the fact that the Catholic Church's identification of and battle against "satanic witches," as heretics subject to torture and death at the stake, did not begin in earnest until Pope Innocent VIII issued a papal bull (Summis desiderantes affectibus) in 1484 authorizing the "correcting, imprisoning, punishing and chastising" of devil worshipers.

And another: in defending the pagan continuity hypothesis, Muraresku presumes a somewhat non-Jewish, pagan-like Jesus, while ignoring the growing body of psychedelic literature, including works by Shanon (2008), Merkur (2000) and Nemu (2019), documenting entheogen use in the Old Testament. Not only was Jesus a Jew; he was the Messiah. Therefore, one could reasonably expect that the author of TIK would look for evidence of a psychedelic precedent for the Eucharist in Judaism. Or, even more broadly, among the religious sects such as the Gnostics, Neoplatonists and Serapis that possessed entheogenic knowledge and that thrived in the circum-Mediterranean region in which Christianity arose (Brown \& Lupu, 2014). In addition to a Hellenic Jesus, why not at least consider a Gnostic Jesus?

Undoubtedly, TIK's most extreme example of overreach is its postulation of a chain of linear historical diffusion from 
Stone Age mortuary rituals to early Greek and Christian Mysteries, and to medieval witchcraft. Here in order to defend his central thesis, Muraresku executes a series of intellectual somersaults that are best tenuous and at worst unsubstantiated.

TIK will entice general readers but exasperate academics, even those who may agree with its specific conclusions regarding the role of entheogens in the Eleusinian Mysteries or early Christianity. Despite its popular appeal as a New York Times Bestseller, TIK fails to make a compelling case for its grand theory of the "pagan continuity hypothesis with a psychedelic twist" due to recurring overreach and historical distortion, failure to consider relevant research on shamanism and Christianity, and presentation of speculation as fact.

*Note: TIK uses "kukeon" throughout, which is an alternative spelling of "kykeon" the spelling used in The Road to Eleusis.

\section{REFERENCES}

Brown, J., \& Brown, J. (2016). The psychedelic gospels: The secret history of hallucinogens in Christianity. Rochester, VT: Park Street Press.

Brown, J., \& Brown, J. (2019). Entheogens in Christian art: Wasson, Allegro and the Psychedelic Gospels. Journal of Psychedelic Studies, 3(2), 142-163.
Brown, J., \& Lupu, M. (2014). Sacred plants and the gnostic church: Speculation on entheogen use in early Christian ritual. Journal of Ancient History, 2(1), 64-77.

Furst, P. T. (1976). Hallucinogens and culture. San Francisco, CA. Chandler \& Sharp Publishers.

Merkur, D. (2000). The mystery of manna: The psychedelic sacraments of the Bible. Rochester, VT: Park Street Press.

Nemu, D. (2019). Getting high with the most high: Entheogens in the Old Testament. Journal of Psychedelic Studies, 3(2), 117132.

Ruck, C. A. P., \& Hoffman, M. A. (2012). The effluents of deity: Alchemy and psychoactive sacraments in Medieval and Renaissance art. Durham, NC: Carolina Academic Press.

Ruck, C. A. P., Hoffman, M. A., \& Celdran, J. A. G. (2011). Mushrooms, Myth and Mithras: The drug cult that civilized Europe. San Francisco: City Lights Books.

Ruck, C., Staples, B., \& Heinrick, C. (Eds.) (2001). The apples of Apollo: Pagan and Christian mysteries of the Eucharist. Durham, NC: Carolina Academic Press.

Samorini, G. (1998). Mushroom-trees in Christian art. Eleusus, 8, 30-37.

Shanon, B. (2008). Biblical entheogens: A speculative hypothesis. Time and Mind: The Journal of Archaeology, Consciousness and Culture, 1(1), 51-74.

Wasson, R. G., Hofmann, A., \& Ruck, C. A. P. (1978). The road to Eleusis: Unveiling the secret of the mysteries. New York, NY: Harcourt, Brace Jovanovich. 